\title{
Seroprevalence of Toxoplasma gondii IgG antibody in HIV-infected patients at the Lagos University Teaching Hospital
}

This article was published in the following Dove Press journal:

HIVIAIDS - Research and Palliative Care

2 September 201 I

Number of times this article has been viewed

\author{
Vincent O Osunkalu' \\ Sulaimon A Akanmu' \\ Nkolika J Ofomah' \\ Igwebuike V Onyiaorah ${ }^{2}$ \\ Adewumi A Adediran' \\ Ralph O Akinde ${ }^{3}$ \\ Ifeanyi A Onwuezobe ${ }^{4}$ \\ 'Department of Haematology \\ and Blood Transfusion, College of \\ Medicine Idi-Araba, Lagos, Nigeria; \\ ${ }^{2}$ Department of Histopathology, \\ Nnamdi Azikiwe University, \\ Nnewi Campus, Lagos, Nigeria; \\ ${ }^{3}$ Department of Morbid Anatomy, \\ College of Medicine Idi-Araba, Lagos, \\ Nigeria; ${ }^{4}$ Department of Microbiology, \\ University of Calabar, Nigeria
}

Correspondence:Vincent O Osunkalu Department of Haematology and Blood Transfusion, College of Medicine IdiAraba, Lagos, Nigeria

Tel +2348023214816

Fax +234 | $585 \mid 432$

Email doctorvincent4real@yahoo.com
Background: Toxoplasmosis is caused by infection with a ubiquitous intracellular protozoan parasite, Toxoplasma gondii. With the advent of the HIV pandemic in Nigeria, toxoplasmic encephalitis has become one of the more frequent opportunistic infections and the most commonly implicated cause of focal brain lesions complicating the course of AIDS.

Objectives: This study was conducted to compare the pattern of seroprevalence of $T$. gondii (Toxo-IgG) antibodies among HIV-infected persons presenting with neurological complications and those without.

Materials and methods: Plasma specimens collected from 380 subjects were tested for Toxo-IgG antibodies by enzyme immunoassay technique and CD4 estimation by flow cytometry. Close-ended questionnaires were applied to all respondents to collect relevant data, with ethical approval from the hospital ethical committee. Plasma was obtained from two study groups comprising $300 \mathrm{HIV}$-positive respondents without neurological presentations, and $80 \mathrm{HIV}$ positive respondents with neurological complications.

Results: Seroprevalence of Toxo-IgG antibodies was 58\% in the HIV-positive study group without neurological complications (of these, $79.2 \%$ were males and $38.5 \%$ were females) and $40 \%$ in the study group with neurological complications $(46.2 \%$ of these were males and $28.6 \%$ were females). The overall seroprevalence of Toxo-IgG antibodies among the HIV-positive respondents (with and without neurological complications) was 54.2\% (206 of $380)$. Seroprevalence of Toxo-IgG antibodies was lowest among the educated subjects (19\% of the respondents with tertiary education) and among females in both study groups. A higher proportion of the subjects with neurological complications had CD 4 cell count $<100$ cells $/ \mu \mathrm{L}$ compared with respondents without neurological defects ( $39 \%$ vs $22.7 \% ; P=0.000)$, but the seroprevalence of Toxo-IgG antibodies was higher in subjects without neurological complications $(45 \%$ vs $31.3 \%$; $P=0.000)$.

Conclusion: Toxoplasmosis, though an important opportunistic infection in our environment, may not account for the majority of neurological complications observed in patients with HIV infection in our center.

Keywords: Toxoplasma gondii antibody (Toxo-IgG), seroprevalence, neurological complication

\section{Introduction}

Toxoplasmosis is caused by infection with a ubiquitous intracellular protozoan, Toxoplasma gondii. ${ }^{1}$ Reproduction is both sexual and asexual. Sexual reproduction occurs in definitive hosts mostly involving the cat family, and occasionally mice or rats. ${ }^{1}$ Asexual reproduction occurs in a wide range of animals, which includes man as intermediate host. ${ }^{1,2}$ The onset of cellular immunity against $T$. gondii is mediated by T-cells, 
macrophages, and activities of type-1 cytokines (interleukin-1 and interferon gamma). This is accompanied by the transformation of the parasite into tissue cysts resulting in chronic infection. ${ }^{3}$ Humoral immune response is initiated by the production of specific Toxoplasma gondii antibodies toxoplasma antibodies (IgM and IgG). ${ }^{3}$ IgM antibody response occurs as an early event, and disappears within a few weeks or months, thus its presence in plasma indicates recent infection. ${ }^{3,4}$ IgG antibody production peaks within 1 to 2 months after infection but remains elevated for life. ${ }^{4}$ Several methods for diagnosis of toxoplasmosis exist and include: isolation in vivo (mice) and in vitro (tissue culture); detection of $T$. gondii by DNA polymerase chain reaction (PCR) from body fluids; computed tomography $(\mathrm{CT})$ scan and magnetic resonance imaging. ${ }^{5-8}$ Serologic testing remains the routine method of diagnosis, ${ }^{4}$ especially in resource-poor countries where it is the most available and affordable means of detecting the presence of Toxoplasma gondii antibodies (Toxo-IgG and IgM antibodies) and IgM antibodies. It has been documented that more than $97 \%$ of HIV-infected individuals with toxoplasma encephalitis will test positive for Toxo-IgG antibodies. ${ }^{4}$ Therefore, the absence of Toxo-IgG antibodies in plasma strongly argues against the diagnosis of toxoplasmosis. ${ }^{4}$ Serological studies in many groups have shown that about $20 \%$ of people would have acquired the infection by the age of 20 , and up to $50 \%$ by the age of $70 .{ }^{4}$ Primary infection in a normal, immunocompetent individual is usually subclinical or associated with self-limiting nonspecific symptoms like fever and malaise. ${ }^{9}$ However, in immunocompromised patients such as HIVinfected persons, reactivation of latent disease can cause life threatening encephalitis; ${ }^{2}$ offspring of infected mothers may present with mental retardation, blindness, epilepsy, or stillbirth. ${ }^{10}$ Toxoplasmic encephalitis has become one of the most frequent opportunistic infections complicating HIV infection, and the most common cause of focal brain lesion, coma, and death.

In Nigeria, management of patients presenting neurological symptoms poses a major clinical challenge because of the numerous possible differential diagnoses, which commonly include central nervous system lymphoma, fungal abscess, mycobacterial infection, cytomegaloviral and other direct viral infections, and Kaposi's sarcoma among others for which diagnostic procedures may be cumbersome and expensive to undertake. ${ }^{9}$ This study therefore was designed to compare the pattern of seroprevalence of Toxo-IgG antibodies in HIV-infected persons without neurological deficits, and HIV-infected persons manifesting any form of neurological complications including motor weaknesses and speech disturbances, seizures, cranial nerve abnormalities, sensory disturbances, cerebellar dysfunction, meningismus, movement disorders, and neuropsychiatric manifestations, and to determine the proportion of these patients whose neurological deficits may be remotely attributable to $T$. gondii infection

\section{Materials and methods Study location}

This study was carried out at the Lagos University Teaching Hospital, Lagos State in the south-west region of Nigeria. Ethical approval for the study was obtained from the hospital ethical committee. Participants were recruited from the out-patient clinic of the hospital, which had over 6000 registered HIV-positive patients from different socioethnic backgrounds.

\section{Study population}

Three hundred and eighty subjects who screened and confirmed positive for HIV-1 or -2 were recruited by random sampling technique at the point of registration. The $380 \mathrm{HIV}$-positive respondents were separated into 2 study groups based on the presence of clinical evidence of neurological symptoms. Of the participants, 300 were without any obvious neurological symptoms while 80 of the HIV-positive participants presented with symptoms which included: neck stiffness, photophobia, tremors, irrational talk, paraesthesia, insomnia, and persistent headache, as isolated disorders or in any combination.

Patients with previous history of anti-retroviral drug therapy, cerebrovascular accidents, septrin prophylaxis, pyrimethamine, and chemotherapy were excluded from the study.

\section{Sample collection and processing}

Two venous blood samples of $4.5 \mathrm{~mL}$ each were drawn from each subject into Na-EDTA specimen tubes. Plasma was obtained by centrifugation at $3000 \mathrm{rpm}$ for 5 minutes, and stored at $-20^{\circ} \mathrm{C}$, prior to Toxo-IgG assay. All collected plasma were analyzed using ELISA by Immuno-comb Toxo-IgG kit manufactured by Orgenics Ltd, Yavne, Israel, with a sensitivity of $97.2 \%$ and specificity of $93.75 \%$. CD4 estimation was carried out with a flow cytometer (Partec-model SL3).

\section{Interpretation of results}

Positive control must produce 2 spots on the card tooth to be valid; negative control must produce only an upper control spot to be valid. A lower spot with an intensity higher than or equal to that of positive indicates the presence of $\operatorname{IgG}$ antibody to Toxoplasma gondii. 


\section{Statistical analysis}

The data were analyzed using statistical software SPSS version 11 (SPSS Inc, Chicago, IL). The data on qualitative variables were indicated by frequency and percentages, and quantitative variables by range and mean. Associations were verified by Chi-square with level of significance placed at $P<0.05(5 \%)$.

\section{Results}

\section{Demographic characteristics (Tables I and 2)}

Mean ages of participants (HIV-positive subjects with neurological symptoms and HIV-positive subjects without neurological symptoms) were $39.5 \pm 4.8$ years and $38.4 \pm 7.2$ years respectively. A higher proportion of the subjects ( 140 of $380,36.7 \%$ ) were between the age range of 37 to 46 years.

Of the respondents, 196 were males (51.6\%) and 184 were females (48.4\%). Most respondents (264 of 380, $69.5 \%$ ) were married. Only $31.6 \%$ of HIV-positive subjects had a tertiary education (120 of 380). The neurological symptoms manifested by these HIV-positive respondents were: headache $(20 \%)$, neck stiffness $(14 \%)$, photophobia $(6.3 \%)$, paraesthesia $(6.3 \%)$, tremor $(20 \%)$, irrational talk $(20 \%)$, and insomnia (14\%). Of these, tremor, headache, and irrational talk constituted the majority of the clinical presentations $(60 \%)$.

\section{Seroprevalence of Toxo-lgG antibody among respondents (Tables 2 and 3 )}

Seroprevalence of Toxo-IgG antibody was $40 \%$ among the HIV-positive study group with neurological symptoms and

Table I Demographic characteristic of subjects

\begin{tabular}{lll}
\hline Characteristics & $\begin{array}{l}\text { HIV patients } \\
\text { with neurological } \\
\text { symptoms }\end{array}$ & $\begin{array}{l}\text { HIV patients } \\
\text { without neurological } \\
\text { symptoms }\end{array}$ \\
\hline $\begin{array}{l}\text { Total number } \\
\text { of subjects }\end{array}$ & 80 & 300 \\
$\begin{array}{l}\text { Age (years) } \\
\text { Sex of subjects }\end{array}$ & $\mathbf{N}(\%)$ & $38.6 \pm 7.2$ \\
Male & $52(26.5)$ & $\mathbf{N}(\%)$ \\
$\begin{array}{l}\text { Female } \\
\text { Educational }\end{array}$ & $28(15.2)$ & $144(74.5)$ \\
background & $\mathbf{N}(\%)$ & I56 (84.8) \\
Primary & $\mathbf{N}(\%)$ \\
Secondary & $40(20.7)$ & $51(76.1)$ \\
Tertiary & $24(20)$ & $153(79.3)$ \\
\hline
\end{tabular}

Table 2 Seroprevalence of anti-Toxoplasma gondii (Toxo-lgG), sex and age of all respondents (with and without neurological symptoms)

\begin{tabular}{|c|c|c|c|c|c|}
\hline Age & $\begin{array}{l}\text { Toxo-IgG } \\
\text { +ve N (\%) }\end{array}$ & $\begin{array}{l}\text { Toxo-IgG } \\
\text {-ve N (\%) }\end{array}$ & Total & $\mathrm{Chi}^{2}$ & $P$-value \\
\hline \multicolumn{6}{|c|}{ Subjects with neurological complication } \\
\hline $16-26$ & $4(25)$ & $12(75)$ & 16 & 5.28 & 0.15 \\
\hline $27-36$ & $8(40)$ & $12(60)$ & 20 & & \\
\hline $37-46$ & $12(60)$ & $8(40)$ & 20 & & \\
\hline$>46$ & $8(33)$ & $16(67)$ & 24 & & \\
\hline \multicolumn{6}{|l|}{ Sex } \\
\hline Male & II 4 (79) & $30(21)$ & 144 & 50.93 & 0.00 \\
\hline Female & $60(39)$ & $96(6 \mathrm{I})$ & 156 & & \\
\hline \multicolumn{6}{|c|}{ Subjects without neurological complication } \\
\hline \multicolumn{6}{|c|}{ Age } \\
\hline $16-26$ & $15(50)$ & $15(50)$ & 30 & 25.99 & 0.00 \\
\hline $27-36$ & $51(50)$ & $5 I$ (50) & 102 & & \\
\hline $37-46$ & $90(75)$ & $30(25)$ & 120 & & \\
\hline$>46$ & $18(38)$ & $30(62)$ & 48 & & \\
\hline \multicolumn{6}{|l|}{ Sex } \\
\hline Male & $24(46)$ & $28(54)$ & 52 & 54.07 & 0.02 \\
\hline Female & $8(29)$ & 20 (7I) & 28 & & \\
\hline
\end{tabular}

$58 \%$ among the HIV-positive study group without neurological symptoms $(P=0.00)$.

There was a higher seroprevalence of Toxo-IgG antibodies among the age range of $37-46$ years (102 of 140) representing $72.9 \%$ of the total in that age group. This was statistically significant at $P=0.00$.

\section{Toxo-lgG antibody and associated factors in HIV-infected respondents (Tables 3 and 4)}

Of the 380 HIV-positive subjects, 206 were seropositive for Toxo-IgG antibodies (54.2\%). Toxo-IgG antibody was more prevalent among the male subjects (70.4\%). However this association was only statistically significant among the study group without neurological symptoms $(P=0.00)$.

CD4 count of all HIV-positive respondents ranged between 7 and 772 cells $/ \mu \mathrm{L}$, with a median count of 320 cells $/ \mu \mathrm{L}$. Of the HIV-positive study group without neurological complications who had CD4 count below 100 cells $/ \mu \mathrm{L}, 79.4 \%$ were seropositive for Toxo-IgG antibody (statistically significant, $P=0.00$ ), compared with $32.2 \%$ in subjects with neurological complications.

The association between Toxo-IgG antibody and HIV infection was more significant among the HIV-positive study group without neurological symptoms $(P=0.00)$. Seroprevalance of Toxo-IgG antibody in the HIVpositive study group with neurological deficit was only 
Table 3 Association between anti-Toxoplasma gondii (Toxo-lgG) antibody and symptoms of neurological disorders in the HIV-positive subjects

\begin{tabular}{|c|c|c|c|c|c|}
\hline $\begin{array}{l}\text { Toxo-IgG } \\
\text { antibody status }\end{array}$ & $\begin{array}{l}\text { Symptomatic } \\
\text { subjects: } \mathbf{N}(\%)\end{array}$ & $\begin{array}{l}\text { Asymptomatic } \\
\text { subjects: } \mathbf{N}(\%)\end{array}$ & Total & $\mathrm{Chi}^{2}$ & $P$-value \\
\hline Positive & $32(40)$ & I74 (58) & 206 & 8.24 & 0.00 \\
\hline Negative & $48(60)$ & $126(42)$ & 174 & & \\
\hline
\end{tabular}

demonstrable in $40 \%$ of the total respondents (32 of 80 ), compared with $58 \%$ in subjects without neurological complications.

\section{Discussion}

In this study, the data showed a Toxo-IgG antibody seroprevalence rate of $54.2 \%$ in HIV-infected persons. Earlier serological studies in many groups showed that the prevalence varied depending on the geographical location, between $15 \%$ and $68 \%$. A recent US survey estimated a prevalence rate of $15 \%$ in the general population ${ }^{11}$ and $40 \%$ in people with HIV. ${ }^{11}$ Nissapatorn et al evaluated the prevalence in 505 HIV-positive patients admitted to a hospital in Malaysia and reported a prevalence of $44.8 \%{ }^{12}$ Wanachiwanawin et al estimated a prevalence rate of $53.7 \%$ in the HIV-infected population in Thailand. ${ }^{13}$ Meisheri et al in India reported a prevalence rate of $30.9 \%$ and $67.8 \%$ in the immunocompetent group and HIV-infected persons respectively. ${ }^{14}$ Galva Ramirez et al estimated a prevalence rate of 50\% in the HIV-infected population in Mexico. ${ }^{15} \mathrm{In}$ Africa, Lindstrom et al evaluated $130 \mathrm{HIV}$-positive patients in Uganda and estimated a prevalence rate of $54 \%{ }^{16}$ The prevalence rate in this study equates well to that seen in the African study in Uganda, and that seen in Mexico.

The slight variations in prevalence rates obtained in this study compared with other earlier studies could be attributed to differences in geographical location. Infection is more common in warm climates, and at lower altitudes than in cold climates and mountainous regions. ${ }^{12}$ However, public enlightenment/health education, and high Human

Table 4 Association between CD4 count and prevalence of antiToxoplasma gondii (Toxo-lgG) antibodies among subjects

\begin{tabular}{|c|c|c|c|c|c|}
\hline $\begin{array}{l}\text { CD4 } \\
\text { (cells/ } / \mu \mathrm{L})\end{array}$ & $\begin{array}{l}\text { Toxo-IgG } \\
\text { tre N (\%) }\end{array}$ & $\begin{array}{l}\text { Toxo-IgG } \\
\text {-ve N (\%) }\end{array}$ & Total & $\mathrm{Chi}^{2}$ & $P$-value \\
\hline \multicolumn{6}{|c|}{ Subjects with neurological complications } \\
\hline$\leq 100$ & $10(32.2)$ & $21(67.1)$ & 31 & 5.28 & 0.15 \\
\hline$\geq 100$ & $22(44.1)$ & $27(55.1)$ & 49 & & \\
\hline \multicolumn{6}{|c|}{ Respondent without neurological complications } \\
\hline$\leq 100$ & $54(79.4)$ & $14(20.6)$ & 68 & 16.55 & 0.00 \\
\hline$\geq 100$ & $120(5 \mid .7)$ & $112(48.3)$ & 232 & & \\
\hline
\end{tabular}

Development Index (HDI) standards could also be responsible for reduced infection.

The overall seroprevalence was highest $(72.9 \%)$, in the 37 to 46 year age group, which is in agreement with an earlier report by Meisheri et al, which showed the highest prevalence within third and fourth decades of life. ${ }^{14}$ However, Nissapatorn et al reported the highest prevalence rate within the second and third decades of life. ${ }^{12}$ The increasing prevalence rate with increasing age could be explained by increased risk of exposure to infection with increasing age. There is no statistical significant difference in age distribution between HIV-infected patients with neurological symptoms and those without.

Most Toxo-IgG antibody seropositive cases were males. The sex predilection could be attributed to the higher risk of consumption of meat (more likely to be contaminated) among Nigerian males. ${ }^{16}$ There was an association between a CD4 count $<100$ cells $/ \mu \mathrm{L}$ and Toxo-IgG antibody seropositivity in HIV-positive subjects without neurological symptoms: $79.4 \%$ of the HIV-positive study group without neurological symptoms who had a CD4 count $<100$ cells $/ \mu \mathrm{L}$ were seropositive for Toxo-IgG antibodies $(P=0.00)$. But this association was not observed in subjects with neurological symptoms $(32.2 \% ; P=0.26)$. Studies by Eliaszewicz et al in France, which included 172 HIV-infected subjects with diagnosed cerebral toxoplasmosis, showed that $79 \%$ of these patients had CD4 count $<150$ cells $/ \mu \mathrm{L} .{ }^{17}$ This result is contrary to findings in this study, which may further confirm the earlier position that neurological complication among HIV-positive subjects may be significantly unrelated to toxoplasmic infections. Johnson and Sayles studied resistance to $T$. gondii infection in mice lacking CD4 expression, and concluded that CD4-deficient mice exhibited impaired resistance to a challenge infection with virulent tachyzoites ${ }^{18}$ therefore HIV infection increases susceptibility to $T$. gondii infection (not necessarily with toxoplasmic encephalitis). Thus CD4 serves as a reliable indicator for possible toxoplasmosis, and also contributes significantly to protection against chronic $T$. gondii infections via their role as helper cells for production of isotype-switched antibodies. ${ }^{18}$ However, findings from this study showed that only $40 \%$ 
of all respondents with neurological complications were seropositive for Toxo-IgG antibody compared with 58\% of HIV-positive subjects without neurological complications. This implies that $60 \%$ of the subjects with neurological complications actually have other possible etiological factors; therefore the occurrence of neurological complications among participants in this study is not associated with higher incidence of Toxo-IgG antibody seropositivity compared with HIV-positive subjects without neurological deficit, thus implying that neurological complications observed in this study group might be from direct invasion of the neural cells by the HIV virus, or other common differentials.

\section{Conclusion}

In this study, the seroprevalence rate of Toxo-IgG antibody in HIV-infected patients, with and without neurological deficits, was evaluated. It may be concluded that though T. gondii infection is highly prevalent in our environment, it may not be responsible for the majority of cases of neurological disorders observed in our HIV-positive patients. However, extensive study in this area, using more accurate methodology including CT scan and PCR techniques, may be needed to establish the exact incidence of toxoplasmic encephalitis in these patients and evaluate differentials.

\section{Disclosure}

The authors declare no conflicts of interest.

\section{References}

1. Wilson M, McAuley JB. Toxoplasma Manual of Clinical Microbiology, 7th ed, Murray P. editor, Washington DC: ASM Press; 1999;35: 1374-1382.

2. Montoya JG, Hesenfeld O. Toxoplasmosis. Lancet. 2004;363(9425): 1965-1976.

3. Subauste CS, Remington JS. Immunity to Toxoplasma gondii. Curr Opin Immunol. 1993;5(4):532-537.

4. Montoya JG, Remington JS. Toxoplasma gondii. In: Mandell GL, Beneth JE, Dohin R, editors. Principles and Practice of Infectious Diseases. Philadelphia: Churchill Livingstone; 2000:2858-2888.
5. Bretagne S, Costa JM, Fluery-Feith J, Poron F, Dubreuil-Lemaire ML, Vidaud M. Quantitative competitive PCR with broncho-alveolar lavage fluid for diagnosis of toxoplasmosis in AIDS patients. J Clin Microbiol. 1995;33(6):1662-1664.

6. Danise A, Cinque P, Vergani S, et al. Use of polymerase chain reaction assays of aqueous humor in the differential diagnosis of retinitis in patients infected with human immunodeficiency virus. Clin Infect Dis. 1997;24(6):1100-1106.

7. Levy RM, Rosenbloom S, Perrett LV. Neurologic findings in AIDS; a review of 2000 cases. AJR AM J Roetgenol. 1986;147(5):977-983.

8. Levy RM, Mills CM, Posin JP, Moore SO, Rosenblum ML, Bredesn DE The efficacy and clinical impact of brain imaging in neurological symptomatic AIDS patients a prospective CT/MRI study. $J$ Acquir Immune Defic Syndr. 1990;3(5):461-471.

9. Navia BA, Petito CK, Gold JW, Cho ES, Jordan BD, Price RW. Cerebral toxoplasmosis complicating the acquired immune deficiency syndrome: clinical and neuropathological findings in 27 patients. Ann Neurol. 1986; 19(3):224-238.

10. Foulon W. Treatment of toxoplasmosis during pregnancy: a multicenter study of impact on fetal transmission and children's sequelae at age 1 year. Am J Obstet Gynecol. 1999;180:410-415.

11. Lones JL, Kruzson D. Toxoplasma gondii infection in US 1999-2000. Emerg Infect Dis. 2003;9:11.

12. Nissapatorn V, Lee CKC, Cho SM, et al. Toxoplasmosis in HIV/AIDS patients in Malaysia. Southeast Asian J Trop Med Public Health. 2003; 34(2):80-85.

13. Wanachiwanawin D, Sutthent T, Chokephaibultkit K, Mahakittikun V, Ongrotchnakun J, Monkong N. Toxoplasma gondii antibodies in HIV and non HIV infected Thai pregnant women. Asian Pac J Allergy Immunol. 2001;19:291-293.

14. Meisheri YV, Mehta S, Patel U. A prospective study of seroprevalence of Toxoplasmosis in general population, and in HIV/AIDS patients in Bombay, India. J Postgrad Med. 1997;43:93-97.

15. Galva Ramirez ML, Valdez Alvarodo V, Vargas Gutierrez G, Jimenez Gonzalez O, Garcia Cosio C, Vielma Sandoval M. Prevalence of IgG and Igm anti-Toxoplasma antibodies in patients with HIV and AIDS. Rev Soc Bras Med Trop. 1997;30:465-467.

16. Lindstrom I, Kaddu-Mulindwa DH, Kironde F, Lindh J. Prevalence of latent and reactivated Toxoplasma gondii parasites in HIV-patient from Uganda. Acta Trop. 2006;100(3):218-222.

17. Eliaszewicz M, Lecomte I, De Sa M. Relation between decreasing series CD4 lymphocyte count and outcome of toxoplasmosis in AIDS patients: a basis for primary prophylaxis. Int Conf AIDS. 1990;6(242): $20-23$.

18. Johnson LL, Sayles PC. Deficient humoral responses underlie susceptibility to Toxoplasma gondii in CD4-deficient mice. Infect Immun. 2002;70(1):185-219.
HIV/AIDS - Research and Palliative Care

\section{Publish your work in this journal}

HIV/AIDS - Research and Palliative Care is an international, peerreviewed open-access journal focusing on advances in research in HIV, its clinical progression and management options including antiviral treatment, palliative care and public healthcare policies to control viral spread. The journal welcomes original research, basic science,

\section{Dovepress}

clinical \& epidemiological studies, reviews \& evaluations, expert opinion \& commentary, case reports \& extended reports. The manuscript management system is completely online and includes a very quick and fair peer-review system. Visit http://www.dovepress.com/ testimonials.php to read real quotes from published authors. 